\title{
Teacher's Digital Skills in Relation to Their Age, Gender, Time of Usage and Training with a Tablet
}

\author{
Lorenia Cantú-Ballesteros ${ }^{1}$, Maricela Urías-Murrieta ${ }^{2}$, Sebastián Figueroa-Rodríguez ${ }^{3}$, Guillermo M. Salazar-Lugo ${ }^{4}$ \\ ${ }^{1,2,4}$ Academic Direction of Social Sciences and Humanities, Department of Education, Instituto Tecnológico de Sonora, \\ Sonora, México \\ ${ }^{3}$ Faculty of Psychology, Universidad Veracruzana, Veracruz, México \\ Correspondence: Maricela Urías Murrieta, Academic Direction of Social Sciences and Humanities, Department of \\ Education, Instituto Tecnológico de Sonora, Sonora, México.
}

Received: February 3, 2017

doi:10.11114/jets.v5i5.2311
Accepted: March 23, $2017 \quad$ Online Published: March 29, 2017

URL: https://doi.org/10.11114/jets.v5i5.2311

\begin{abstract}
The present studies objective was to determine the digital level capabilities of primary school teachers and their relation with certain sociodemographic factors. The focus was quantitative and a cross-sectional survey design for two or more groups was used. The sample was non-probabilistic and included 88 fifth and sixth grade teachers from 32 schools from Cd. Obregón and Navojoa, Sonora. The results showed that $65.9 \%$ of the teachers, were perceived at a intermediate level of their digital skills. That in the Operation and Concepts of ICT, the set of teachers was placed at an expert level with an average of $4.33(0.64)$. While in the Communication and Collaboration, they were perceived at the level without the use of the ICT, an average of $1.78(0.59)$. On their part, the test t of Student revealed significant differences between the digital skill variable and its factors: Operation and Concept of the ICT, Communication and Collaboration, and Critical Thinking and Information Management, with the contrasting variables: daily hours that the teacher destines to the use of the computer/tablet to support their subjects, weekly hours that the teacher destines to the use of the computer/tablet in the classroom to support their subjects and related training with the use of the ICT. Finally, the results are discussed as well as their possible implications.
\end{abstract}

Keywords: digital skills, full time schools, information and communication technologies, basic education, teacher

\section{Introduction}

The society in which we live requires its citizens to display various competences to deal with the challenges of today and tomorrow, without doubt the Information and Communication Technologies (ICT) are configured to achieve that level of competence (Martínez, 2009). The continuous use of (ICT) in educational processes allows students to acquire abilities that will lead them to be proficient in searching, analysis and evaluation of information, the approach and problem solving and decision making. Thus, it is required of teachers to support them in the acquisition of said competences (United Nations Educational, Scientific and Cultural Organization [Unesco], 2008).

With this approach, the teacher transforms into the main actor of education, as it becomes solely their decision whether or not to incorporate said technology in the classroom (Suárez-Rodríguez, Almerich, Díaz-García, \& Fernández-Piqueras, 2012). Acting as mediators, they are the one responsible for fusing the ICT with teaching and knowledge, designing adequate and innovating environments inside and outside the classroom. Thus, a set of competences or digital skill that allows them to integrate said resources in this daily pedagogical practice is required (Suárez-Rodríguez et al., 2012); and stimulate the students through the acquisition of basic knowledge in ICT, and further advance with them through the deepening of knowledge, finally reaching the generation of the aforementioned (Unesco, 2008).

In this context, governments and international organisms like Unesco, the International Society for Technology in Education (ISTE), the Chilean Ministry of Education and the Secretary of Public Education (SEP, for its acronym in Spanish) among others, have developed standards in the use of the ICT for the different actors of education (teachers, students, administrators and principals). However, this and other efforts made with the intention of consolidate the digital abilities required in the classroom haven't been enough. Different international references confirm it such is the case in the research conducted by Suárez, Almerich, Gargallo, and Aliaga (2010) that report the teachers of basic education with a limited level of technological and pedagogical competencies; with remarkable deficiencies in the use 
of educational software, multimedia, programming and web design. Likewise Almerich, Suaréz, Jornet, and Orella (2011) indicate a low level of competence and use of technological resources from the teachers, especially in funtionalities, tools and advanced actions and are profiled as users instead of educational material producers or technology enriched environments for education. At last in the work of Vargas-D'Uniam, Chumpitaz-Campos, Suárez-Díaz, and Badia (2014), it's concluded that the teachers show a low development of digital competence and a basic level in technological resources uses, mostly in interaction and communication with students and the simulation of scenarios. As well as limitations in functionalities, tools and ICT advanced actions.

For Mexico, the basic education scenario has not been different either; at least two identified national studies corroborate it. In the first one of them, the author reports that $43.5 \%$ of primary school teachers, are placed in the level "none and little knowledge of the ICT", on the base scale of a Likert-type scale with options of: none, little, regular, average or above average knowledge from teachers on the ICT (Ramírez, 2012). On the second case, the high school teachers are perceived as digitally competent on the factors: Instrumental and Cognitive and Non-Competent: in the Didactic-Methodological (Mortis, Valdés, Angulo, García, \& Cuevas, 2013). Said results show the complexity of the topic and invite reflection because, in spite of different programs having been launched by the SEP to consolidate the pedagogical use of the ICT: Full Time Schools (ETC, for its acronym in Spanish) and its digital skills development line, Digital Capabilities for Everyone (HDT, for its acronym in Spanish) and the Inclusion and Digital Literacy Program (PIAD, for its acronym in Spanish), teachers still presenting low levels in the digital skills.

Due to the aforementioned, some studies have deepened their results, including the level of digital ability of the teacher, the identification and analysis of the context variables of sociodemographics that relate or influence these skills. Highlighting the age and gender of the teacher, the frequency with which they use a computer, the education level, the use of a multimedia classroom, Internet and computer at home and the training received, among others, are the ones that present significant relations (Almerich et al., 2011; Mortis et al., 2013; Suárez et al., 2010; Ramírez, 2012).

In this order of ideas, it is stated that the recent incorporation of the digital skill standards in Mexico within the 2011 study plan (SEP, 2011) and the development of digital skills (Martínez, 2009; SEP, 2009), have propitiated that the studies in the subject for elementary school education, are scarce, generating a lack of empirical results that sustain actions or strategies to strengthen or improve the digital skills of the teacher in the pedagogical use of the ICT. For this reason and after three years of the implementation in Sonora of two important initiatives to promote the development of digital skills, the ETC program and the PIAD, it was necessary to identify:

What is the digital ability level that the teachers of the ETC present?

What factors of a teacher's digital skill are more or less developed? And;

If there are significant differences between the level of digital skill of the teachers and its factors, with the sociodemographic variables: age, gender, daily hours that the teacher assigns to the use of the computer/tablet to support his subjects, weekly hours that the teacher assing to the use of the computer/tablet in the classroom to support their subjects, Internet access from home and training related with the pedagogical use of the ICT?

To answer these questions, and having as a reference the standards of digital skills proposed by SEP (2011), ISTE (2008) and Unesco (2011), an instrument for measuring the self-perception of digital skills for teachers was designed and applied (see appendix). These skills are defined as: the ethical and responsible use that the teacher give to media and digital environments to communicate ideas, information and collaboration with students, coworkers and parents. As well as the support given to the students in acquirement and comprehension of concepts, systems and functioning of ICT. And in the creativity development, innovation, critical thinking, problem solving, decision making, searching, selection, analysis and evaluation of information (SEP, 2011).

Taking into account the performed revision and the investigation inquiries, the present study proposes the following general objective: determine the level of digital skills of full-time elementary school teachers and its relation with the sociodemographic variables age, gender, daily hours that the teacher destines to the use of the computer/tablet to support their subjects, weekly hours that the teacher destines to the use of the computer/tablet within the classroom to support their subjects and the related training with the pedagogical use of the ICT.

\section{Method}

\subsection{Research Design}

The research utilized a survey desing to compare two or more groups. This design is considered as part of the process of the quantitative methodology and as intentional changes in the environment or treatment of the participants are not involved, it was classified as non-experimental. Data was collected in one instance and unique time, thus, the design used was designated as cross-sectional. At last, the investigation was proposed to compare two or more groups on their level of digital skills of the teachers and their factors of age, sex, time of use of tablets and training, with the purpose of make inferences about the data (Creswell, 2012). 


\subsection{Participant Characteristics}

The population was selected from an universe of 3,664 teachers and 793 ETC public of the state of Sonora (Subsecretariat of Basic Education [SEB] for its acronym in Spanish, 2015), with the following criteria of inclusion and exclusion: a) location in Cd. Obregon y Navojoa; b) enrolment in the ETC program, in the cycles 2013-2014 and/or 2014-2015; c) elementary school level, excluding, pre-school and middle school; d) general modality, except: indigenous and multiple care center, e) complete organization, dismissing: multigrade and f) $5^{\text {th }}$ grade and $6^{\text {th }}$ grade, discarding: $1^{\text {st }}, 2^{\text {nd }}, 3^{\text {rd }}$ and $4^{\text {th }}$ grade (see table 1 ).

In accordance with the above criteria, the population was defined as $35 \mathrm{ETC}$ and 120 fifth and sixth-grade teachers.

Table 1. Definition of inclusion and exclusion criteria

\begin{tabular}{ll}
\hline Criteria & Definition \\
\hline Pre-school & Educational level with three academic grades $\left(1^{\circ}-3^{\circ}\right)$ for children from 3 to 5 years old. \\
Elementary & Educational level with six academic grades $\left(1^{\circ}-6^{\circ}\right)$ for children from 6 to 12 years old.
\end{tabular}

school

Middle school Educational level with three academic grades $\left(1^{\circ}-3^{\circ}\right)$ for children from 13 to 15 years old.

ETC program Strategy proposed by SEP in Mexico that extends the academic day to strengthen the development of competence of the students. It impulses six lines of work: deepen the curriculum, develop digital skills, strengthen communicative and social competence, enhance the artistic creativity, look after the cultural heritage, achieve physical development and promote healthy living.

General This modality in elementary school includes the schools in which a relatively large group attends simultaneously.

modality

Indigenous Elementary schools with ethnical and cultural diversity that require specialized professors that speak Spanish and modality the native language of the students.

Multiple care Offers elementary school education for students that have a disability or have special educational needs.

center modality

Complete organization

Multigrade

Organization in elementary schools in which each grade has a professor. organization

Organization in which one of more professors simultaneously attends more than one grade in the same classroom.

Own elaboration from Antonio (2009); Instituto Nacional para la Evaluación de la Educación (2009); Ordanika and Rodríguez-Gómez (2012)

\subsection{Sampling Procedures}

The final sample was composed of 88 teachers from 32 ETC and was extracted through non-probabilistic sampling of voluntary participation. Its main characteristics are presented in table 2 and 3.

Table 2. Sample characteristics, sociodemographic variables

\begin{tabular}{|c|c|c|c|c|}
\hline \multicolumn{5}{|l|}{ Sociodemographic variables } \\
\hline Sex & Female & $55.7 \%$ & Male & $44.3 \%$ \\
\hline Civil status & Married & $75.0 \%$ & Single & $25.0 \%$ \\
\hline Employment situation & Contract & $87.5 \%$ & Intern & $12.5 \%$ \\
\hline Level of studies & Undergraduate degree & $68.2 \%$ & Postgraduate degree & $31.8 \%$ \\
\hline Disposition of the MX tablet & Yes & $84.1 \%$ & No & $15.9 \%$ \\
\hline Internet access sites & Home & $69.3 \%$ & School & $54.4 \%$ \\
\hline Technological equipment layout & Laptop & $84.0 \%$ & Smartphone & $83.0 \%$ \\
\hline Lowest use of tablet in subjects & Math & $25.0 \%$ & Civic y Ethic Formation & $15.9 \%$ \\
\hline Highest use of tablet in subjects & Natural Sciences & $54.5 \%$ & Spanish & $46.6 \%$ \\
\hline
\end{tabular}

Table 3. Sample characteristics, sociodemographic variables

\begin{tabular}{lllll}
\hline Sociodemographic variables & $M$ & $D S$ & Minimum & Maximum \\
\hline Age & 35 & 7.66 & 24 & 52 \\
Years of experience as a teacher & 12.32 & 7.13 & 2 & 28 \\
Seniority in the group & 1.51 & 2.01 & 0 & 11 \\
No. of coursers in ICT (2 years) & 2.00 & 1.43 & 0 & 8 \\
Hr/day use of the PC/tablet & 1.97 & 1.53 & 0 & 9 \\
Hr/week use de la PC/tablet in the classroom & 4.56 & 2.54 & 0 & 10 \\
Hr/week use of the Internet in the classroom & 3.02 & 3.01 & 0 & 10 \\
No. days that the tablet is required & 3.00 & 1.36 & 0 & 5 \\
\hline
\end{tabular}

\subsection{Measures}

For the data compilation, a questionnaire was used for the self-perception of teachers' digital abilities (see appendix), which was elaborated using the ICT standards and competences of ISTE (2008), SEP (2011) and Unesco (2011). It was structured regarding three factors: a) Operation and Concepts of ICT; b) Communication and Collaboration and c) Critical Thinking and Information Management. It consisted of two sections, one with 18 general data items and the 
other one with 14, distributed among the three factors: four, five and five, respectively. For the latter, a Likert-type scale was used, with five response options: never (1), almost never (2), sometimes (3), almost always (4) and always (5).

\subsubsection{Validity}

Content validity was made through experts' judgments, following the process of Escobar-Pérez and Cuervo-Martínez (2008). And for the calculation of concordance between the judges, the coefficient of content validity (CVC, for its acronym in Spanish) of Hernández (2012) was used. Once the process was completed, the final instrument consisted of 30 items, which met CVC values greater than .80 (Hernández, 2012) and a total CVC of .92.

For the construct validity, the exploratory factor analysis technique ([AFE], for its acronym in Spanish, (Martínez, Hernández, \& Hernández, 2014) was used, based on the proposals of Osborne (2008) and Kline (1994), for samples smaller than 100 cases. It was based on 30 items, distributed in six theoretical dimensions: a) creativity and innovation; b) communication and collaboration; c) research and management of information; d) critical thinking, problem solving and decision making; e) digital citizenship and f) operation and concepts of ICT. The AFE results, using the Maximum Likelihood and Oblimin rotation method, showed a measure of Kaiser-Mayer-Olkin (KMO) sample adequacy of .858 and a significant Bartlett sphericity test; with an $\mathrm{X}^{2}=744.47$ and a $\mathrm{p}=<.001$, showing suitability in the data for this type of analysis. An integrated solution of three factors was obtained: Operation and Concept of ICT (33.68\%, 4 items); Communication and Collaboration $(20.01 \%, 5$ items) and Critical Thinking and Information Management $(8.76 \%, 5$ items), which together accounted for $62.45 \%$ of the variance.

\subsubsection{Reliability}

For reliability, the Cronbach's alpha coefficient was used (Bojórquez \& López, 2013). The obtained results, by factor and global, were superior to .70 , which represented a strong internal consistency of the answers. The overall index was .87 and by factor: Operation and Concept of ICT $(.85,5$ items); Communication and Collaboration ( $.86,4$ items) and Critical Thinking and Information Management (.87, 5 items).

\subsection{Process}

In order to obtain the information, ETC principals were asked to authorize the survey of fifth and sixth-grade teachers. In turn, teachers were asked to respond a questionnaire that was given and collected later, not before explaining: the purpose of the study, the importance of their voluntary participation and the confidentiality of information.

\subsection{Data Analysis}

For the analysis of data, descriptive and inferential statistics were used with the support of the statistical package SPSS 22.0 and Excel 14.6.1. To describe the characteristics of the sample, a unvaried analysis (means, standard deviations, percentages, maximum and minimum) was performed. In order to establish the validity of the instrument, the CVC was used (Hernández, 2012) and the AFE (Martínez et al., 2014). For reliability, we worked with Cronbach's alpha coefficient (Bojórquez \& López, 2013). And finally, to establish the differences between groups, we worked with Student's t-test.

\section{Results}

\subsection{Digital Skills of the Teachers}

In order to determine the digital abilities of the teachers, the self-perception tool described in the previous section was used and to classify them by levels, the ISTE (2008) assessment matrix proposal was adopted to meet their ICT standards for teachers. Of the four levels proposed by ISTE (2008), the superior called: transformer was not considered and in its place was included another, which presented the teacher in the absence of uses of ICT in pedagogical practice, resulting in the following classification: no use of the ICT, beginner level, intermediate level and expert level.

Based on the above proposal, most teachers were perceived at an intermediate level of their digital ability, with some teachers standing out in the expert (see table 4). Also, of the set of factors that explained the level of digital ability of teachers, the Operation and Concept of ICT located teachers at an expert level. While the factor of Communication and Collaboration placed them in the inferior level, no use of the ICT (see figure 1).

Table 4. Placement of teachers by their level of digital ability

\begin{tabular}{llll}
\hline Skill level & Average & Frequency & Percentage \\
\hline No use of the ICT & 1.0 a 2.0 & 3 & 3.40 \\
Beginner & $>2.0$ a 3.0 & 20 & 22.70 \\
Intermediate & $>3.0$ a 4.0 & 58 & 65.90 \\
Expert & $>4.0$ a 5.0 & 7 & 8.00 \\
\hline
\end{tabular}




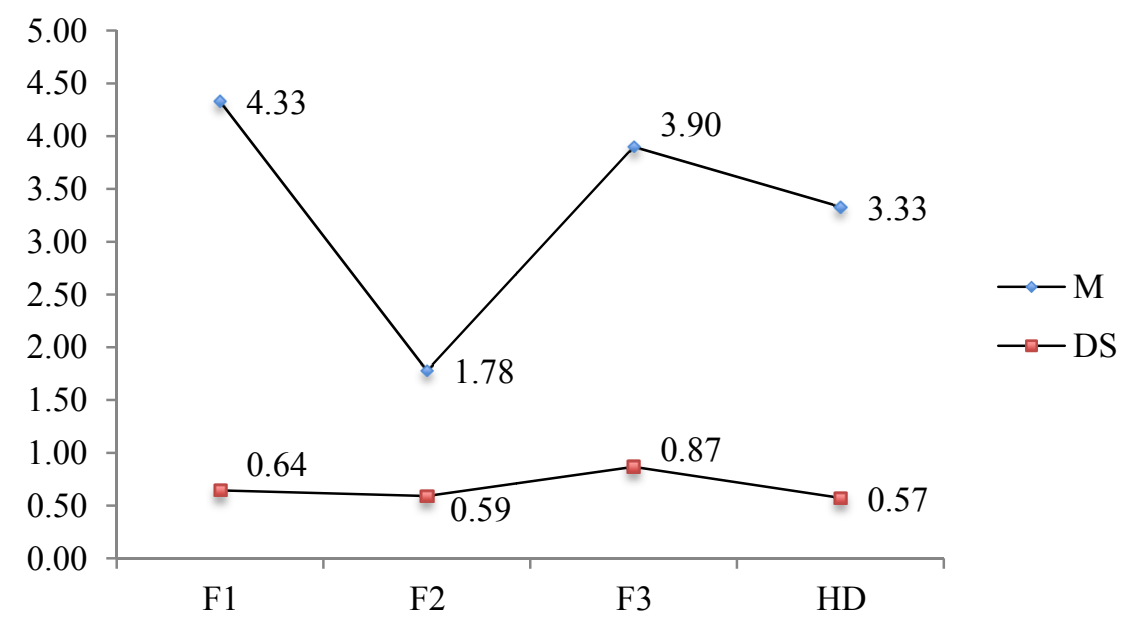

Figure 1. Mean and standard deviations of the teachers' digital ability and their factors

F1 = Operation and Concepts of ICT; F2 = Communication and Collaboration; F3 = Critical Thinking and Information Management and $\mathrm{HD}=$ Digital Ability

\subsection{Digital Teachers' Abilities According to Socio-Demographic Factors}

In order to identify the existence of significant differences between the teacher's digital ability and their factors, as a function of age, a Student's t-test was used for independent samples. To achieve this, teachers were separated by age into two groups using Prensky (2001) as work criteria, which identified users of the technology as: native and digital immigrants (these last born in the pre-digital age before 1990). The first included 24- and 36-year-olds (young adults) and the second, 37- and 52-year-olds (mature adults). The test revealed significant differences, with only the factor of Critical Thinking and Information Management, obtaining a higher mean for young adults (see table 5).

Table 5. Comparisons of ETC teacher scores by age

\begin{tabular}{|c|c|c|c|c|c|c|c|}
\hline \multirow[b]{2}{*}{ Factor/Variable } & \multicolumn{2}{|c|}{ Young adults } & \multicolumn{2}{|c|}{ Mature adults } & \multirow[b]{2}{*}{$t(86)$} & \multirow[b]{2}{*}{$p$} & \multirow{2}{*}{$\begin{array}{c}\text { Cohen's } \\
d\end{array}$} \\
\hline & $M$ & $S D$ & $M$ & $S D$ & & & \\
\hline Operation and Concept of ICT & 4.39 & 0.76 & 4.25 & 0.81 & 0.81 & .421 & 0.17 \\
\hline Communication and Collaboration & 1.83 & 0.58 & 1.73 & 0.60 & 0.77 & .441 & 0.16 \\
\hline Critical Thinking and Information Management & 4.05 & 0.77 & 3.72 & 0.77 & 2.08 & $.048^{*}$ & 0.44 \\
\hline Digital Skills & 3.42 & 0.55 & 3.23 & 0.59 & 1.57 & .119 & 0.33 \\
\hline
\end{tabular}

$* p<.05$.

Table 6 shows the results according to the sociodemographic variable gender. These showed the absence of significant differences in the digital ability and its factors, associated to this variable.

Table 6. Comparisons of ETC teacher scores by gender

\begin{tabular}{|c|c|c|c|c|c|c|c|}
\hline \multirow[b]{2}{*}{ Factor/Variable } & \multicolumn{2}{|c|}{ Female } & \multicolumn{2}{|c|}{ Male } & \multirow[b]{2}{*}{$t(86)$} & \multirow[b]{2}{*}{$p$} & \multirow{2}{*}{$\begin{array}{c}\text { Cohen's } \\
d\end{array}$} \\
\hline & $M$ & $S D$ & $M$ & $S D$ & & & \\
\hline Operation and Concept of ICT & 4.35 & 0.85 & 4.29 & 0.70 & 0.35 & .728 & 0.07 \\
\hline Communication and Collaboration & 1.74 & 0.54 & 1.82 & 0.64 & -0.64 & .524 & -0.14 \\
\hline Critical Thinking and Information Management & 3.98 & 0.83 & 3.79 & 0.76 & 1.06 & .291 & 0.22 \\
\hline Digital Skills & 3.36 & 0.60 & 3.30 & 0.54 & 0.43 & .664 & 0.09 \\
\hline
\end{tabular}

${ }^{*} p<.05$.

Continuing with the Student $t$ test, the variable digital abilities and its factors were compared with the variable: hours per day that the teacher intended to use the computer/tablet. At this point, the teachers were separated into two groups, starting from the minimum identified time that was $0 \mathrm{hr}$ and the maximum of $9 \mathrm{hr}$. The first group included those who reported from $0 \mathrm{hr}$ up to $1 \mathrm{hr} 59 \mathrm{~min}$ (null-low use) and the second group, who indicated from $2 \mathrm{hr}$ up to $9 \mathrm{hr}$ (medium-high use).

The results of the test identified significant differences in the Communication and Collaboration factor and in the digital abilities. In both cases, the average was higher for teachers who used two or more hours of computer/tablet to support the development of their subjects (see table 7). 
Table 7. Comparisons of the teacher's ETC scores for hours per day destined to the use of the computer/tablet to support the development of their subjects

\begin{tabular}{|c|c|c|c|c|c|c|c|}
\hline \multirow[b]{2}{*}{ Factor/Variable } & \multicolumn{2}{|c|}{ Null-low use } & \multicolumn{2}{|c|}{$\begin{array}{l}\text { Medium-high } \\
\text { use }\end{array}$} & \multirow[b]{2}{*}{$t(86)$} & \multirow[b]{2}{*}{$p$} & \multirow{2}{*}{$\begin{array}{c}\text { Cohen's } \\
d\end{array}$} \\
\hline & $M$ & $S D$ & $M$ & $S D$ & & & \\
\hline Operation and Concept of ICT & 4.25 & 0.79 & 4.40 & 0.79 & -0.91 & .364 & 0.19 \\
\hline Communication and Collaboration & 1.53 & 0.42 & 2.02 & 0.63 & -4.21 & $<.001^{* *}$ & -0.90 \\
\hline Critical Thinking and Inf. Management & 3.77 & 0.79 & 4.02 & 0.80 & -1.44 & .153 & -0.31 \\
\hline $\begin{array}{l}\text { Digital Skills } \\
\text { Diflu }\end{array}$ & 3.18 & 0.50 & 3.48 & 0.60 & -2.48 & $.015^{*}$ & -0.53 \\
\hline
\end{tabular}
$* p<.05, * * p<.001$.

Also the variable was contrasted: hours per week that the teacher destines to the use of the computer/tablet in the classroom to support their subjects. For this analysis, the teachers were separated into two groups starting from the minimum reported time that was $0 \mathrm{hr}$ and the maximum of 10 . The first group included the teachers who assigned from $0 \mathrm{hr}$ to $4 \mathrm{hr} 59 \mathrm{~min}$ (null-low use) and the second, who indicated from $5 \mathrm{hr}$ to $10 \mathrm{hr}$ (medium-high use).

The test revealed significant differences in all factors in specific and in digital ability in general. In all cases, the average was higher for teachers who assigned five to more hours a week (medium-high use), to the use the computer/tablet to support the development of their subjects in the classroom (see table 8).

Table 8. Comparisons of ETC teachers' scores for hours per week for the use of the computer/tablet in the classroom to support their subjects

\begin{tabular}{|c|c|c|c|c|c|c|c|}
\hline \multirow[b]{2}{*}{ Factor/Variable } & \multicolumn{2}{|c|}{ Null-low use } & \multicolumn{2}{|c|}{$\begin{array}{l}\text { Medium-high } \\
\text { use }\end{array}$} & \multirow[b]{2}{*}{$t(86)$} & \multirow[b]{2}{*}{$p$} & \multirow{2}{*}{$\begin{array}{c}\text { Cohen's } \\
d\end{array}$} \\
\hline & $M$ & $S D$ & $M$ & $S D$ & & & \\
\hline Operation and Concept of ICT & 4.15 & 0.86 & 4.49 & 0.68 & -2.05 & $.044^{*}$ & -0.43 \\
\hline Communication and Collaboration & 1.57 & 0.44 & 1.98 & 0.64 & -3.51 & $.001^{*}$ & -0.74 \\
\hline Critical Thinking and Information & 3.69 & 0.86 & 4.09 & 0.69 & -2.45 & $.016^{*}$ & -0.52 \\
\hline Management & & & & & & & \\
\hline Digital Skills & 3.14 & 0.59 & 3.52 & 0.49 & -3.34 & $.001^{*}$ & -0.71 \\
\hline
\end{tabular}

$* p<.05$.

Also, a student's t test was used, with the intention of establishing a relation between the variable skills ability and the factors that explain it, with the variable: number of training courses received in the last two years, related to the pedagogical use of ICT. In order to carry out the test, the teachers were separated into two groups, taking into account the minimum number of courses received that was zero and the maximum number of eight. The first group included those who reported from zero to two courses (null-low training) and the second, those who took three to eight (medium-high training).

The results of the test presented significant differences in the digital skills variable and the three factors. In all cases, the average was higher for teachers who took three to eight courses; with medium-high training (see table 9).

Table 9. Comparisons of ETC teachers' scores for training related to the pedagogical use of ICT

\begin{tabular}{|c|c|c|c|c|c|c|c|}
\hline \multirow[b]{2}{*}{ Factor/Variable } & \multicolumn{2}{|c|}{$\begin{array}{l}\text { Null-low } \\
\text { training }\end{array}$} & \multicolumn{2}{|c|}{$\begin{array}{l}\text { Medium-high } \\
\text { training }\end{array}$} & \multirow[b]{2}{*}{$t(86)$} & \multirow[b]{2}{*}{$p$} & \multirow{2}{*}{$\begin{array}{c}\text { Cohen's } \\
d\end{array}$} \\
\hline & $M$ & $S D$ & $M$ & $S D$ & & & \\
\hline Operation and Concept of ICT & 4.22 & 0.81 & 4.61 & 0.65 & -2.14 & $.035^{*}$ & -0.54 \\
\hline Communication and Collaboration & 1.70 & 0.53 & 1.99 & 0.69 & -2.13 & $.036^{*}$ & -0.48 \\
\hline Critical Thinking and Information & 3.78 & 0.81 & 4.21 & 0.67 & -2.34 & $.022^{*}$ & -0.58 \\
\hline Digital Skills & 3.23 & 0.57 & 3.61 & 0.49 & -2.86 & $.005^{*}$ & -0.70 \\
\hline
\end{tabular}
$* p<.05$.

\section{Discussion}

In the present study, the level of digital abilities of full-time elementary school teachers and their relation to sociodemographic variables were determined: age, gender, hours per day that the teacher destines to use the computer/tablet to support their subjects, hours per week that the teacher destines to the use of the computer/tablet in the classroom to support their subjects and the training related to the pedagogical use of ICT.

In relation to the level of digital skills of teachers, the results showed that the majority of the participants were placed at an intermediate level; this means that they were perceived with more expertise and flexibility in the use of ICT in an educational environment (ISTE, 2008). However, the sample still identifies the presence of a group of teachers ranking among the no use and beginners ICT levels, suggesting that there are still difficulties to incorporate and use ICT in pedagogical practices. This finding coincided with the work of Almerich et al. (2011), Suárez et al. (2010) and Ramírez 
(2012), who reported teachers with low ICT skills; with limited technological and pedagogical skills; and with "none and little knowledge of ICT", respectively. It also highlighted the presence of a minority group of teachers who have managed to position themselves at the expert level that were perceived as efficient and effective users of ICT to improve student learning (ISTE, 2008). However, the analysis made it possible to identify that at least two variables were significant to obtain said expert level of ability (training in the pedagogical use of ICT and the time spent using the computer/tablet to support the development). Both factors have been reported as facilitators for ICT inclusion by authors such as de Pons, Colas and González (2010); González and de Pablos (2015) and Parra, Gómez, and Pintor (2015).

Also, teachers were perceived at an expert level in the Operation Factor and Concept of ICT; meaning, they were considered capable of using technology (tablet, applications, Internet, etc.) in a productive way, as well as transferring their knowledge towards learning new ICT. This result agreeded with the work of Mortis et al. (2013), who found that the teachers were competent in the Instrumental factor; which, although it does not have the same name as the present study, can be considered equivalent to include similar indicators in its definition.

For the Communication and Collaboration factor, the situation behaved differently, since the collective of teachers were located at the level: no use of the ICT. These findings coincided with other studies that indicated a lack of competence for teachers in the communication section (Ramírez, 2012) and a lower proportion of ICT use to enhance communication through technological means (Sigalés, Mominó, Meneses, \& Badia, 2008). Although it is necessary to go deeper into the subject, this may be due to: the lack of Internet service in schools and the lack of training received in the pedagogical use of ICT, both problems reported in the Beltrán, García, and Ramírez (2015a, 2015b) investigations.

In order to establish the relations between the sociodemographic variables, with the teacher's digital abilities and their factors, in the study were performed analysis using Student's t-test. The findings for the age variables, confirmed the existence of significant differences only for the factor of Critical Thinking and Information Management, with a higher average (expert level) for teachers called: young adults (24-36 years). Previous studies have shown that at a younger age, teachers present greater digital competences (Almerich et al., 2011; Mortis et al., 2013; Suárez-Rodríguez et al., 2012). However, the presence of differences in a single factor could be indicative that this tendency is being modified, violating the proposal of digital natives and immigrants (Prensky, 2001).

Whilst it is true that the reviewed literature shows significant differences starting from the sociodemographic gender variable, attributing higher abilities to teachers (Suárez et al., 2010; Suárez-Rodríguez et al., 2012; Rámirez, 2012). The performed analysis during this investigation, through a t Student test, didn't show significant differences associated with the variable.

The variable associated with the hours per day that a teacher destines to the use of a computer/tablet to support the development of their subjects, showed significant differences regarding the Communication and Collaboration factor and the digital ability variable. And for the contrast variable: hours per week that the teacher destines to the use of a computer/tablet within the classroom to support their subjects, the differences were identified among all factors and digital ability. For both contrast variables, the teacher's digital abilities and its factors were greater for those who spent more time at it. These results were consistent with those reported by Almerich et al. (2011) and Mortis et al. (2012), who found significant relations between teacher's digital competences compared to a higher use of a computer. The aforementioned confirms the necessity to establish strategies that stimulate the teacher to increase the time dedicated to support the development of their subjects, regarding planning as well as support within the classroom. Taking into account the time variable, this is considered to be one of the main barriers for the integration of the ICT (Ermert, 1999; González \& de Pablos, 2015).

Finally, the sociodemographic variable of related training with the pedagogical use of ICT, backed up the important this has within the development of teacher's digital abilities. The significant differences were identified amongst all factors and digital ability, attributing in all cases the higher average to those that received more training. Similar findings were reported by Mortis et al. (2013). Thus, it is important to look for pertinent strategies that allow to increase the training of teachers, considering this points towards the elements that allow to promote XXI century abilities among students (Binkley et al., 2012).

As far as study limitations, this also identified the instrument, which belongs to the auto perception category, and thus subject to slant. Nevertheless and due to the scarce empirical evidence within this subject, including contextualized questionnaires availability to measure digital abilities. It is concluded that the instrument designed for this study is valid and reliable to the purpose for which it was created and thus, can be used as a tool capable of guiding future investigations regarding elementary school teacher's digital abilities. This will, no doubt, allow strengthening the instrument and showing more clarity about teacher's perceptions.

To conclude, the recommendation given for future works is to move forward towards the use of multivariate statistical methods. This will allow to address the subject of teacher's digital abilities, simultaneously from different variables. 


\section{References}

Almerich, G., Suárez, J. M., Jornet, J. M., \& Orellana, M. N. (2011). Las competencias y el uso de las Tecnologías de Información y Comunicación (TIC) por el profesorado: estructura dimensional. REDIE. Revista Electrónica de Investigación Educativa, 13(1), 28-42. Retrived from http://www.redalyc.org/articulo.oa?id=15519374002

Antonio, L. (2009). Caja de herramientas. La tarea educativa de una escuela de tiempo completo. Una mirada desde la dirección escolar. México: Secretaría de Educación Pública.

Beltrán, J. A., García, R. I., \& Ramírez, M. S. (noviembre, 2015a). Usabilidad y apropiación del programa "Mi CompuMx" desde la perspectiva de los docentes de primaria. En M. C. Barrón (Presidente). Aportes y reflexiones desde la investigación educativa: ¿qué sabemos... que nos falta?. XIII Congreso Nacional de Investigación Educativa, Chihuahua, México. Retrived from http://ciie.itesm.mx/es/memorias/

Beltrán, J. A., García, R. I., \& Ramírez, M. S. (November, 2015b). Percepción docente sobre sus experiencias con el programa "Mi CompuMx" En M. C. Barrón (Presidente). Segundo Congreso Internacional de Innovación Educativa, México. D.F. Retrived from http://ciie.itesm.mx/es/memorias/

Binkley, M., Erstad, O., Hermna, J., Raizen, S., Ripley, M., Miller-Ricci, M., \& Rumble, M. (2012). Defining twenty-firtst century skills. En P. Griffin, E. Care, \& B. McGaw (Eds.). Assessment and Teaching of 21st Century Skills. Methods and approach. (pp. 1-267). https://doi.org/10.1007/978-94-017-9395-7

Bojórquez, J. A., \& López, L. (2013, Agosto 14). Utilización del alfa de Cronbach para validar la confiabilidad de un instrumento de medición de satisfacción del estudiante en el uso del software Minitab. En R. Lorán (Presidente), Innovation in engineering, technology and education for competitiveness and prosperity. 11 th Latin American and Caribbean Conference for Engineering and Technology, Cancún, México. Retrived from http://www.laccei.org/LACCEI2013-Cancun/RefereedPapers/RP065.pdf

Creswell, J. W. (2012). Educational research: planning, conducting, and evaluating quantitative and qualitative research ( $4^{\mathrm{a}}$ ed.). Boston, United State: Pearson.

de Pablos, J., Colás, P., \& González, T. (2010). Factores facilitadores de la innovación con TIC en los centros escolares. Un análisis comparativo entre diferentes políticas educativas autonómicas. Revista Educación, (352), 23-51. Retrived from http://www.revistaeducacion.educacion.es/re352/re352_02.pdf

Ertmer, P. A. (1999). Addressing first and second order barriers to change: Strategies for technology integration. Educational Technology, Research and Development, 47(4), 47-61. https://doi.org/10.1007/BF02299597

Escobar-Pérez, J., \& Cuervo_Martínez, A. (2008). Validez de contenido y juicio de expertos: Una aproximación de su utilización. Avances en Medición, 6, 27-36. Retrived from http://www.humanas.unal.edu.co/psicometria/files/7113/8574/5708/Articulo3_Juicio_de_expertos_27-36.pdf

González, A., \& de Pablos, J. (2015). Factores que dificultan la integración de las TIC en las aulas. Revista de Investigación Educativa, 33(2), 401-417. https://doi.org/10.6018/rie.33.2.198161

Hernández, R. (2012). Instrumentos de recolección de datos en Ciencias Sociales y Ciencias Biomédicas. Venezuela: Universidad de los Andes.

Instituto Nacional para la Evaluación de la Educación. (2009). Panorama educativo de México. Estructura y dimensión del sistema educativo nacional. México: INEE. Recuperado de http://www.inee.edu.mx/bie_wr/mapa_indica/2009/PanoramaEducativoDeMexico/EstructuraYDimension/Ciclo20 08-2009/2009_Ciclo2008-2009_.pdf

International Society for Technology Education. (2008). ISTE Standards Teacher. En ISTE. Retrived from http://www.iste.org/docs/pdfs/20-14_ISTE_Standards-T_PDF.pdf

Kline, P. (1994). An easy guide to factor analysis. New York: Sage.

Martínez, G. A. (2009). Caja de herramientas. Línea de trabajo desarrollo de habilidades digitales. Guía Metodológica. México: Secretaría de Educación Pública. Recuperado de http://www2.sepdf.gob.mx/petc/archivos-documentos-rectores/guia_habilidades_digitales.pdf

Martínez, M. R., Hernández, M. J., \& Hernández, M. V. (2014). Psicometría. Madrid, España: Alianza Editorial. Retrived from http://site.ebrary.com/lib/biblioitsonsp/detail.

Mortis, S., Valdés, A., Angulo, J., García, R. I, \& Cuevas, O. (2013). Competencias digitales en docentes de educación secundaria. Municipio de un estado del noroeste de México. Perspectiva Educacional. Formación de Profesorado, 52(2), 135-153. Recuperado de http://www.redalyc.org/articulo.oa?id=333328170007 
Ordorika, I., \& Rodríguez-Gómez R. (2012). Cobertura y estructura del sistema educativo mexicano: problemática y propuestas. En J. Narro, J. Martuscelli, \& E. Barzana (Eds.). Plan de diez años para desarrollar el Sistema Educativo Nacional. México: Dirección General de Publicaciones y Fomento Editorial, UNAM. Recuperado de http://www.planeducativonacional.unam.mx

Osborne, J. W. (2008). Best practices in quantitive methods. California, Estados Unidos: Sage. https://doi.org/10.4135/9781412995627

Parra, S. R., Gómez, M. G., \& Pintor, M. M. (2015). Factores que inciden en la implementación de las TIC en los procesos de enseñanza-aprendizaje en $5^{\circ}$ de Primaria en Colombia. Revista Complutense de Educación 26[Número Especial], 197-213. https://doi.org/10.5209/rev_RCED.2015.v26.46483

Prensky, M. (2001). Nativos digitales, inmigrantes digitales. Retrived from http://cmapspublic2.ihmc.us/rid=1417883264286_1406133957_69319/NATIVOS\%20E\%20INMIGRANTES\%20 DIGITALES\%20(Prensky).pdf

Ramírez, C. M. (2012). Análisis de las competencias básicas en tecnologías de la información y comunicación (TIC) del profesorado de educación primaria: un plan de formación. Municipio de Comitán Chipias, México (Tesis doctoral). Retrived from http://ddd.uab.cat/pub/tesis/2011/hdl_10803_113680/cmrc1de2.pdf

Secretaría de Educación Pública. (2009). Plan de estudios 2009. Educación básica primaria (2a Ed.). México, D.F.: SEP. Retrived from https://coleccion.siaeducacion.org/sites/default/files/planestedubas09.pdfsat

Secretaría de Educación Pública. (2011). Acuerdo número 559 por el que se establece la articulación de la educación básica. México, D.F.: Secretaría de Educación Pública. Retrived from http://basica.sep.gob.mx/ACUERDO\%20592web.pdf

Sigalés, C., Mominó, J., Meneses, J., \& Badia, A. (2008). La integración de Internet en la educación escolar española: Situación actual y perspectivas de futuro. Barcelona: Ariel. Retrived from

http://www.uoc.edu/in3/integracion_internet_educacion_escolar/esp/pdf/informe_escuelas.pdf

Suárez, J. M., Almerich, G., Gargallo, B., \& Aliaga, M. (2010). Las competencias en TIC del profesorado y su relación con el uso de los recursos tecnológicos. Education Policy Analysis Archives/Archivos Analíticos de Políticas Educativas, 18(10), 1-33. Retrived from http://www.redalyc.org/pdf/2750/275019712010.pdf

Suárez-Rodríguez, J. M., Almerich, G., Díaz-García, I., \& Fernández-Piqueras, R. (2012). Competencias del profesorado en las TIC. Influencia de factores personales y contextuales. Universitas Psychologica, 11(1), 293-309. Retrived from http://www.redalyc.org/articulo.oa?id=64723234024

Subsecretaría de Educación Básica. (2015). Base de datos de las escuelas participantes en el programa escuelas de tiempo completo. Ciclo escolar 2015-2016. Retrived from

http://www.sec-sonora.gob.mx/coordinacion/uploads/BASE\%20DE\%20DATOS\%20AUTORIZADA\%20POR\%2 0DGDGIE\%202015-2016.xlsx

United Nations Educational, Scientific and Cultural Organization. (2008). Estándares de competencias en TIC para docentes. Retrived from http://www.eduteka.org/pdfdir/UNESCOEstandaresDocentes.pdf

United Nations Educational, Scientific and Cultural Organization. (2011). UNESCO ICT competency framework for teacher. Paris, Francia: United Nations Educational, Scientific and Cultural Organization. Retrived from http://unesdoc.unesco.org/images/0021/002134/213475E.pdf

Vargas-D'Uniam, J., Chumpitaz-Campos, L., Suárez-Díaz, G., \& Badia, A. (2014). Relación entre las competencias digitales de docentes de educación básica y el uso educativo de las tecnologías. Profesorado, 18(3), 361-377. Retrived from http://digibug.ugr.es/bitstream/10481/34544/1/rev183COL9.pdf

\section{Appendix}

The professor's instrument

Dear Professor:

We thank you in advance for your participation in the answering of this questionnaire, which serves to identify the perception that you have on your digital skills.

We ask for your complete honesty in each of your answers which will be treated as confidential. The information that you give us will help develop an educational strategy that contributes to the pedagogical integration of the Information and Communication Technologies in schools.

General Instructions 
I. Carefully read each question before answering.

II. Answer all the questions honestly in the answer sheet. There are no right or wrong answers.

GENERAL INFORMATION

1. Age: (Answer on the answer sheet)

2. Marital Status: Single Married

3. Sex: Female Male

4. Antiquity in the school:

5. Years of experience as a teacher:

6. Grades taught:

7. Years of Antiquity in the group:

8. Type of Contract: Permanent Temporary

9. Type of Studies: Normal School Bachelor's Degree Master's Degree Doctorate

10. How many courses relating to the pedagogical use of the ICT has you taken in the last two years?

11. Which of the following equipment do you have in your house? (Select multiple answers if applicable)
Desktop Computer
Laptop Tablet
Smartphone (With apps to the Internet)

12. Which of the following equipment do you have in your school? (Select multiple answers if applicable)
Desktop Computer
Laptop Tablet
Smartphone (With apps to the Internet)

13. From where do you Access the Internet? (Select multiple answers if applicable)
Home School
Cyber Cafe
Mobile Network (Internet from a cellphone or broad band)

14. Approximately How many hours a day do you use the Internet to help in the development of your assignments?

15. Approximately How many hours a week do you use the Internet in the classroom to help with the development of the assignments?

16. Approximately How many hours a week do you use a computer or tablet in the classroom to help with the development of the assignments?

17. How often do you ask your students to take their tablets to school? Days of the week:

18. How often do you use your tablet and its apps in the following subjects?

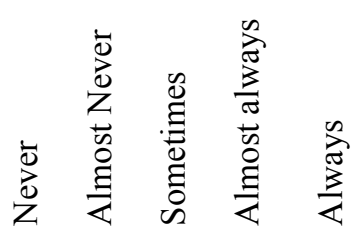

Spanish

Mathematics

Natural Science

Geography

History

Civic and Ethical Formation

Instructions: Carefully read and answer in the answer sheet the option which you consider best represents the frequency with which you perform the following activities:

19. Use of digital means to maintain communication and collaborate with my students in their academic activities such as:

Virtual Learning Platforms (MOODLE, Edmodo).

Social Media Networks (Facebook).

Chat (Hangouts, Whatsapp).

E-Mail (Hotmail, Gmail, Yahoo).

Video Call (Skype).

Micro blog (Twitter).

Wikis (Websites that allow the user to modify or create content).

Blogs (Website where activities or documents are published chronologically)

Forums (Website used to exchange ideas and share opinions on a subject) 
20. Use of digital means to maintain communication and collaborate with my colleagues and exchange information to support academic activities such as:

Virtual Learning Platforms (MOODLE, Edmodo).

Social Media Networks (Facebook).

Chat (Hangouts, Whatsapp).

E-Mail (Hotmail, Gmail, Yahoo).

Video Call (Skype).

Wikis (Websites that allow the user to modify or create content).

Blogs (Website where activities or documents are published chronologically)

Forums (Website used to exchange ideas and share opinions on a subject)

21. Develop activities or projects that require the use of different means of digital communication to spread the collaborative work over distances amongst students that belong to:

The same group

Different school groups

Other schools in the city

Other schools in the country

Other schools from other countries or cultures

22. Develop activities or projects that use some of the following means of communication to support the collaborative work amongst students:

Virtual Learning Platforms (MOODLE, Edmodo).

Social Media Networks (Facebook).

Chat (Hangouts, Whatsapp).

E-Mail (Hotmail, Gmail, Yahoo).

Video Call (Skype).

Micro blog (Twitter).

Wikis (Websites that allow the user to modify or create content).

Blogs (Website where activities or documents are published chronologically)

Forums (Website used to exchange ideas and share opinions on a subject)

23. Ask my students to share the results of their projects or collaborative activities via:

Social Media Networks (Facebook).

Blogs (Website where activities or documents are published chronologically)

Platform made by the professor (MOODLE, Edmodo).

Forums (Website used to exchange ideas and share opinions on a subject)

"Explora" Platform (Project tool).

Micro blog (Twitter).

YouTube.

Oral Presentations assisted by computer and projector

24. Direct my students in the processes of searching for information on the Internet to support their investigations or activities on:

Websites to search for information

Criteria for the search and selection of information

Criteria for the analysis and evaluation of the information

25. I help my students to identify when the sources of information found on the Internet are:

Trustworthy or not

Present incorrect information or some deviation from reality

Present alternative points of view from the information obtained

26. Indicate my students that when analyzing and evaluating the websites in the search of information to at least:

The authority of the web sites (if it is a government site, an educational institution, prestigious organization, etc.)

That the information is updated (Identify the date that the website or information was updated)

That the website has a name

That is has titles and headings

That the vocabulary, the concepts and the language are appropriate for their age. 
27. When I present to my student a problem to solve I guide them to:

Define in a clear and precise way the purpose, this is to say what they want to accomplish or reach.

Define the secondary goals of purposes that support the main purpose.

Redirect thinking towards the original purpose when it is lost.

28. Present the development of technology enriched projects in which my students can:

Propose the topic or identify the problem that needs to be investigated.

Establish the purpose of the project.

Establish the activities necessary to reach the propose of the project.

Determine the sources of information consulted.

Identify the possible solutions to the identified problem.

Propose the expected results.

Determine the times necessary for each activity.

29. I support my students so they can identify with their tablets:

Power Button.

Volume Button

Front-facing camera

Micro SD slot

USB connector

Power Supply

Combo connector (Microphone and earphones).

30. I support my students so they can identify on their tablets the status buttons and shortcuts such as:

Wireless connection status.

Battery charge status.

Back button.

Home Screen.

Current Time.

Volume.

31. I support my students to gain Internet access on their tablets via the following actions

Activate wireless connectivity.

Selecting available wireless connections.

Locate the password.

Enter the Password.

Establish connection.

32. I support my students to organize the information on their tablet through the file administrator using one of the following actions:

List the system folder structure.

Create, copy, erase or rename folders.

Copy, mover, rename and erase files.

\section{Copyrights}

Copyright for this article is retained by the author(s), with first publication rights granted to the journal.

This is an open-access article distributed under the terms and conditions of the Creative Commons Attribution license which permits unrestricted use, distribution, and reproduction in any medium, provided the original work is properly cited. 